\title{
Impacts of Socio-cultural Environment on Psychological Characteristics and Managerial Practices of Women Entrepreneurs in Algeria
}

\author{
Boufeldja Ghiat \\ Labo-EduPsy, Faculty of Social Sciences, Oran II University, Algeria
}

Copyright $(2017$ by authors, all rights reserved. Authors agree that this article remains permanently open access under the terms of the Creative Commons Attribution License 4.0 International License

\begin{abstract}
The traditional positions of Algerian women are housewives, but with the end of the twentieth century, Algerian society begins to see women in positions of responsibility. Many of them chose to be entrepreneurs, which indicate that the country is experiencing profound social and cultural changes. The managerial performances of women entrepreneurs are influenced by their psychological characteristics and the socio-cultural environment and constraints. A questionnaire was developed and the study covered a sample of 30 women entrepreneurs from Oran Algeria, 19 of them are married with children, and 14 of them have a university degree. The results showed that women entrepreneurs have strong personalities, marked by a spirit of adventure and initiative. These qualities are necessary for the success of entrepreneurship. The objective of this paper is to study the socio-cultural environment of entrepreneurship in Algeria, with special attention to women entrepreneurs and their psychological characteristics. The impacts of these factors on managerial practices of women entrepreneurs are pointed out.
\end{abstract}

Keywords Socio-cultural Environment, Psychological Characteristics, Algerian Women Entrepreneurs, Managerial Practice

\section{Introduction}

In Algeria as a males' society, the majority of entrepreneurs are males. But with the increasing number of female graduates from Algerian universities, and with the growing rates of unemployment, the girls begin to move more and more towards entrepreneurship businesses.

Algerian business environment, as a developing country, is characterized by economic and socio-cultural factors, and entrepreneurs have to face a multitude of physical, financial, bureaucratic and human obstacles.

This is not an easy task for men to venture into entrepreneurial activity in an environment full of challenges and constraints. Before opening on the market economy, Algeria has experienced a period of socialism where entrepreneurship was the business of the state. It is a challenge for a woman to venture into an entrepreneurial activity in this type of environment.

After the opening of the market economy in the late 20th century, Algerian women had the opportunity to try entrepreneurial liberal occupations. It is a challenge for a woman to venture into entrepreneurial activity in this hostile cultural environment.

The literature review shows a great similarity regarding socio-cultural constraints of women entrepreneurs in the Maghreb countries (Morocco, Algeria and Tunisia), as a result of belonging to the same Arab-Muslim culture. The socio-cultural environment and constraints are shared also with women entrepreneurs in most developing countries in Africa and Asia. Female entrepreneurship in Algeria is not studied enough, in particular its socio-cultural constraints, and management styles of women entrepreneurs.

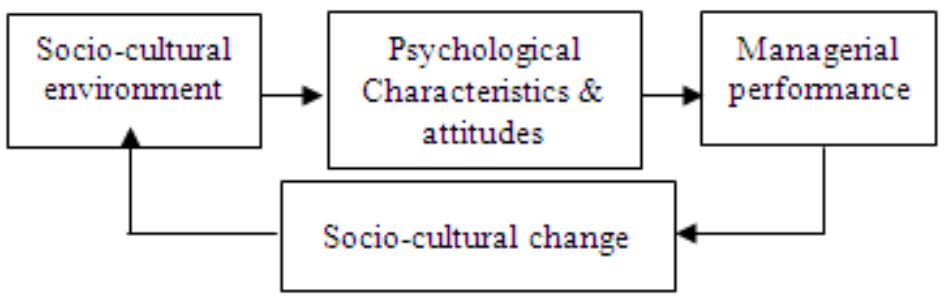

Figure 1. Impacts of socio-cultural environment on managerial performance 
Most women entrepreneurs in Algeria are forced to join entrepreneurship as a result of high unemployment among youth in general mainly during the economic crises which occurred in Algeria during the nineties of the twentieth century. The phenomenon is found in most developing countries, as "the Global Entrepreneurship Monitors (GEM, 2012) posit that in developing countries, the vast majority of women are engaged in entrepreneurial activity driven by pure survival - out of necessity rather than opportunity" (Adebayo [1] ). Women's enterprises are small, mainly in service activities. A woman entrepreneur can be either self-employed working in her own business, or an employer with at least one employee (Rachdi [2] ).

Human resources management requires psychological and managerial skills characters. Management methods must be adapted to the socio-cultural environment. This requires more practical research to better understand the HRM practices of female managers in Algeria and North Africa.

This paper focuses on socio-cultural environment entrepreneurship, on psychological characteristics of women entrepreneurs and their managerial practices.

\subsection{Socio-cultural Environment of Entrepreneurship}

Socio-cultural environment affects entrepreneurial behaviors, and local culture is a basic determinant of human personality and behavior. According to Adebayo, "Culture is a learned behavior which each person acquires as a member of a group or society. That implies that culture is an integrated pattern of human knowledge, belief and behavior that depends upon the capacity for symbolic thought and social learning" (Adebayo [2] ).The roles and behaviors of entrepreneurs are influenced by their socio-cultural environment. 'In the sociologist's study an entrepreneur's role in the socio-cultural aspects that includes his family, socio-cultural status, caste, religion and other affiliations" (Kumar [3] ). The same observation can be found in most underdeveloped countries, as women are often seen as objects of pity, often holding a marginal status against-productive in their societies (Yakubu [4] ).

In the Arab-Muslim culture, several cultural values became obsolete, such as considering that women cannot manage men and being on their heads. That is why many men have difficulties in working under the command of a woman, and receiving orders from them and being obliged to execute women's orders. The culture of a male society is the source of several socio-cultural problems of women entrepreneurs in Algeria. In Algeria, as in developing countries in general, "Socio-cultural factors are deeply rooted elements of a particular society and compass the values, attitudes, norms, practices institutions, stratification and related ways of a society" (Kumar [3] ).

Bensedik and Ouchallal [5] pointed out that "The environment (social, institutional, financial) plays a decisive role, not only in the implementation process, but also psychologically as that it induces an effect on the choice behavior of young entrepreneurs (continuity, abandonment, resistance, motivation, perception of risk, management of the project".

Algerian people as Arabs Muslim in their majority, respect the Islamic religion, its practices and traditions. Women have special position in society. Mixing between genders is very restricted. Beside the religious aspects, we find aspects related to illiteracy, poverty and under development. That led to economic, social and cultural complex problems (management of human resources, production, marketing, relations with the authorities - banks, taxes, suppliers and customers -). All these aspects have repercussions on the entrepreneurial activities.

Managers and employees are influenced by the culture of their environments. The Arab-Muslim culture and cultural traditions are nestled in Algeria as in all Maghreb countries. Management practices and human resource management methods are influenced by the culture of the environment. Among the cultural aspects found, women's working away from their homes, men working under the supervision of women managers or entrepreneurs, male / female relationships at work, and formal / informal relations...

In countries with no industrial economic activities, Cultural constraints became barriers to entrepreneurship activities and women are the first victims.

\subsection{Socio-cultural Constraints of Women Entrepreneurship}

Women's behavior and choice of their occupation are determined by the local culture. Saskia [6] argues that "the gender gap in entrepreneurship is most apparent when reviewed by industry choice and entrepreneurial orientation. Women seem to pursue certain businesses at the expense of others. That is confirmed by Kumar [3] that "Socio-cultural factors are things that can affect our lifestyles as a society. They can have an influence on individual behaviors depending on one's social values. Some of them could be religion, economic status, education, family, politics, cultural values etc. They are the facts and experiences that influence individuals' personality, attitudes and lifestyle".

The same phenomenon is found in most developing countries in Africa and Asia. Shastri \& Sinha [7] "posit that though women entrepreneurs may possess all the required resources and all conditions to exploit entrepreneurial opportunity such as education, experience and energy but the environmental constraints such as lack of credit, and societal discrimination especially in developing countries, may hinder their growth".

Algeria has experienced great cultural and economic changes following the spread of education, including higher education. The girls have become the majority of students in Algerian universities, even in scientific fields of study, known as masculine, such as civil engineering, marine engineering, agronomy and mechanical engineering..., fields used to be reserved mainly for males.

The majority of students in Algerian universities are females, and are hard workers. This reality is not reflected in 
the number of active women entrepreneurs compared to men. "According to Kumar [3] . even though the leadership potential of women is very high, this potential is hidden by social, economic and political constraints".

The majority of enterprises created and managed by women are small businesses, with fewer than five employees among girls, often in their first jobs, activating generally in the informal. The majority of young women entrepreneurs, have no training in human resources management and lack the human resource management experience. Dif and Benyahia-Taibi [8] , pointed out that women entrepreneurship in Algeria is a revolution against some resistance without values that make a woman a human being unable to have an individual project of work, or to approach the area of economic affairs, often reserved for man.

Most constraints of women entrepreneurs are related to socio-cultural environment and the management of human resources. The management of these aspects needs strong personality and psychological characteristics, necessary for the management of human relations. The woman entrepreneur in Algeria undergoes constraints related to the society's values and culture » (Benyahia-Taibi [8] ).

\subsection{Psychological Characteristics of Women Entrepreneurs}

Algerian women have the psychological characteristics necessary for the creation and management of their enterprises, the same as men. But in men's society, males are educated from their childhood, to face environmental constraints, while women are educated to be good wives and good mothers. Cornet and Constantinidis [9] confirmed that women entrepreneurs have specific characteristics and behaviors. Among the psychological characteristics needed, Gasse [10] points out that "typical entrepreneur has strong needs for personal fulfillment, has confidence in himself, likes to be autonomous and independent, likes moderate risk, is motivated and full of energy."

The Algerian socio-cultural environment is characterized by negative attitudes towards women entrepreneurs, that is consolidated by the local culture and the type of socialization young girls which affect their personality and psychological characteristics as known in traditional societies.

Being an entrepreneur requires a strong personality and capacity to manage the behaviors and attitudes of people in a complex and often hostile socio-cultural environment. This requires psychological qualities such as patience, perseverance, the communication abilities, ability to make decisions, confrontation of clerical, human, technical and material problems; and ability to adapt to changes and unforeseen events, are qualities badly needed for women entrepreneurs.

In his research about Algerian young entrepreneurs, Ziane [11] identified: self-confidence, perception of risks and decision-taking, as important qualities for successful young entrepreneurs.

Several psychological qualities necessary for the success of women entrepreneurs are sometimes contrary to the education imparted to women in Arab-Muslim environments. We also see that the behavior of women is restricted by values, customs and cultural traditions exert more pressure on working women. In this socio-cultural environment, women are often known by their sentimental qualities often cow and easily influenced. Therefore cannot face the difficulties that are usually left for men.

The fact of increasing the number women entrepreneurs in Algeria indicates to deep undergoing changes in the mentality, and that led to the entrance of women into various occupations, including entrepreneurship.

There is a strong link between the psychological characteristics of the entrepreneur and demands entrepreneurial activities. Entrepreneurial culture "values the personal characteristics associated with entrepreneurship is individualism, marginality, the need for personal achievement, risk-taking, self-confidence and social skills; who value personal success while forgiving failure; that encourages diversity and not uniformity, and that encourages change and not stability. " ( Léger-Jarniou [12] ). According to Say, direct and organize the one hand, take risks, on the other hand are the two most characteristic of the entrepreneur activity traits (Tounés [13] ).

In Algeria, women are known by their sentimental characteristics, are often easily influenced by others, and find difficulties to confront difficulties which are usually left for men. The fact that women became entrepreneurs in the Algerian society, explains that there is a deep change in the personality of modern Algerian women.

The importance of psychological characteristics for the entrepreneurial success by Dif and Benyahia-Taibi [8] who pointed out that psychological and intellectual capacities of women provide her with the right and capacity to undertake her business project, that is to be independent and able to carry out her individual project, to the extent that the entrepreneur's profile is based on psychological and rational capacities.

The traditional socialization of Algerian woman was so that psychological characters necessary for entrepreneurial occupations were lacking. According to Rachdi, [2] "The socialization of girls does not help to develop their confidence, their autonomy, sense of risk and their taste for innovation: yet necessary skills for anyone who wants to develop and manage a business ". Fortunately, these educational and socio-cultural constraints are not insurmountable.

\subsection{Managerial performance of Women Entrepreneurs}

Although there are few women entrepreneurs who create medium and large companies, there are several women executives and directors of public companies in senior positions. This demonstrates their capacity to manage, and are not less competent compared to men.

Algerian women are brought up in an underdeveloped environment with plenty of material and socio-cultural 
problems and constraints, inside and outside their families. Therefore they are ready to confront problems while setting up or managing their enterprises. In the absence of Networks and appropriate effective associations, Algerian women entrepreneurs rely on the advice of parents, members of the family or friends, for the management of their enterprises.

In spite of the socio-cultural constraints, Algerian women entrepreneurs execute the works in person whenever possible, consult their assistants, have the communication and leadership qualities, learn from their experiences and develop strategies for adaptation with their socio-cultural environment and even innovate in their managerial practices (Ghiat, [14] ).

Socio-cultural environment and constraints of Algerian women entrepreneurs, their psychological characteristics and managerial practices are investigated in this research.

\section{Methodology}

To study women entrepreneurs in Algeria, a questionnaire was developed and used for the investigation of their psychological characteristics, socio-cultural constraints and managerial skills.

\subsection{Objectives}

The objectives of this research are summarized in the study of the following:

1. The socio-cultural environment of entrepreneurship in Algeria

2. The socio-cultural constraints of women entrepreneurs in Algeria.

3. The psychological characteristics of women entrepreneurs.

4. The managerial practices of women entrepreneurs.

\subsection{Research Questions}

To clarify the issue, several questions are raised:

1. What characterizes the socio-cultural environment of Algerian enterprises?

2. What are the socio-cultural constraints of women entrepreneurs?

3. What are the psychological characteristics of women entrepreneurs?

4. What are the qualities of women entrepreneurs in managerial practices?

A questionnaire was developed to conduct this study and answer these questions.

\subsection{Questionnaire and Data Collection Procedures}

A questionnaire "Indices of Socio-cultural Impacts on Managerial Performances (ISIMP)" was developed in order to collect data on the following aspects:
1. Personal information.

2. Information about the company.

3. Psychological characteristics.

4. Socio-cultural difficulties.

5. Management practices.

The questionnaires were distributed directly to women entrepreneurs who had to choose between "Yes", "No" or "Sometimes". Percentages have been computed, the results are shown in tables (7-11).

\subsection{Sample of the Study}

30 questionnaires were filled from a population of women entrepreneurs from the Oran region, 17 of them were married with children, and 17 of them have university degrees.

\subsubsection{Personal Information}

Table 1. Sample distribution according to ages.

\begin{tabular}{|c|c|c|}
\hline Ages & Frequency & Percent \\
\hline $20-30$ years & 06 & $20.0 \%$ \\
\hline $31-40$ years & 13 & $43.3 \%$ \\
\hline $41-50$ years & 06 & $20.0 \%$ \\
\hline 51 years and more & 05 & $16.7 \%$ \\
\hline Total & 30 & $100 \%$ \\
\hline
\end{tabular}

The age of the majority of women of the sample have between 20 and 40 years old (63.30\%).

Table 2. Sample distribution according to marital status.

\begin{tabular}{|c|c|c|}
\hline Marital status & Frequency & Percent \\
\hline Single & 10 & $33.30 \%$ \\
\hline Married & 17 & $56.61 \%$ \\
\hline Divorced & 01 & $3.33 \%$ \\
\hline Widow & 02 & $6.66 \%$ \\
\hline Total & 30 & $100 \%$ \\
\hline
\end{tabular}

The sample consists of mainly married women $(56.70 \%)$.

Table 3. Sample distribution according to the level of training.

\begin{tabular}{|c|c|c|c|c|}
\hline & Primary & Secondary & University & Total \\
\hline $\begin{array}{c}\text { Level of } \\
\text { instruction }\end{array}$ & 02 & 11 & 17 & 30 \\
\hline Percent & $6.66 \%$ & $36.63 \%$ & $56.61 \%$ & $100 \%$ \\
\hline
\end{tabular}

The majority of women entrepreneurs surveyed have a university level of education $(56.70 \%)$.

\section{Results}

The analysis of data from 30 questionnaires filled by women entrepreneurs helped us to draw the following conclusions: 


\subsection{Socio-cultural Environment of Entrepreneurship in Algeria}

Table 4. Socio cultural environment

\begin{tabular}{|c|c|c|c|c|c|c|c|}
\hline \multicolumn{2}{|r|}{ Socio-cultural environment } & Yes & $\%$ & Some-times & $\%$ & No & $\%$ \\
\hline 1 & My status has improved vis-à-vis the society after creating my business. & 19 & 63.3 & 07 & 23.3 & 04 & 13.3 \\
\hline 2 & The success female entrepreneurship requires a radical change of mentality. & 16 & 59.2 & 07 & 25.9 & 04 & 14.8 \\
\hline 3 & $\begin{array}{l}\text { Algerian society perceives positively the position of the woman } \\
\text { entrepreneur. }\end{array}$ & 11 & 36.7 & 07 & 23.3 & 12 & 40.0 \\
\hline 4 & $\begin{array}{l}\text { The perception of men towards women entrepreneurs is significantly } \\
\text { negative. }\end{array}$ & 08 & 26.7 & 08 & 26.7 & 14 & 46.7 \\
\hline 5 & I am often harassed by men. & 07 & 23.3 & 05 & 16.7 & 18 & 60.0 \\
\hline
\end{tabular}

Based on the responses of the sample (Table 4), we note the importance of socio-cultural constraints that women entrepreneurs face daily.

\subsection{Socio-cultural Constraints of Women Entrepreneurs}

Table 5. Socio cultural constraints:

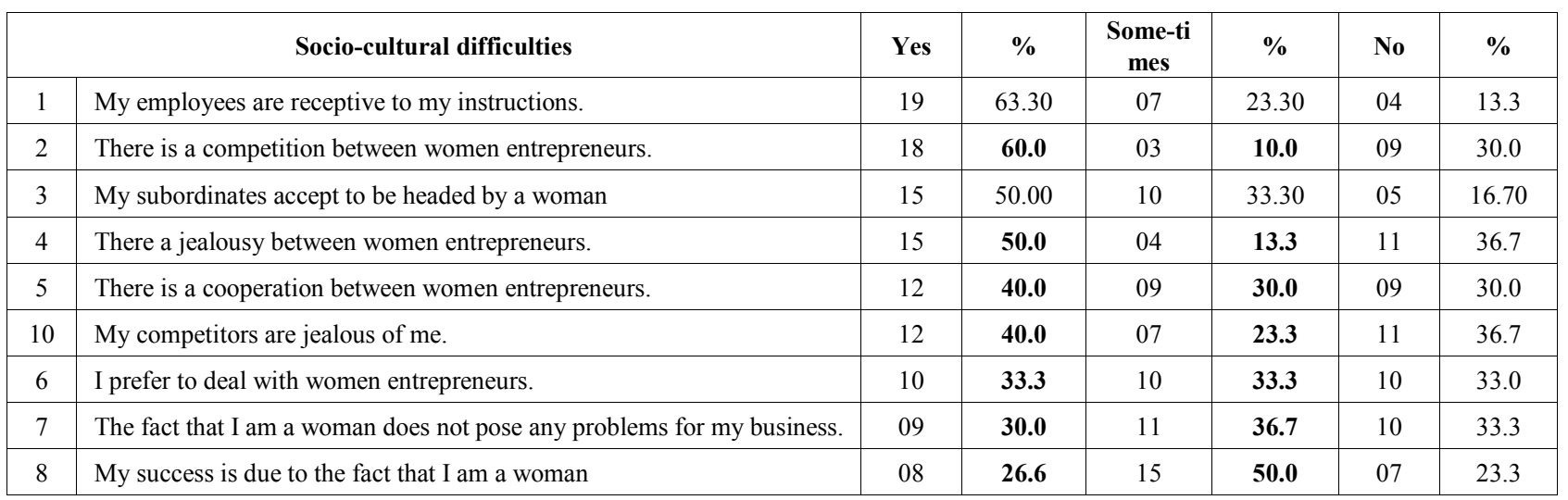

Based on the responses of the sample (Table 5), we note the importance of socio-cultural constraints that women entrepreneurs face daily.

\subsection{Psychological Characteristics of Women Entrepreneurs}

Table 6. Psychological characteristics of women entrepreneurs:

\begin{tabular}{|c|c|c|c|c|c|c|c|}
\hline \multicolumn{2}{|r|}{ Psychological characteristics } & Yes & $\%$ & Sometimes & $\%$ & No & $\%$ \\
\hline 1 & I master the negotiation with my interlocutors. & 26 & 86.70 & 04 & 13.3 & 00 & 00.0 \\
\hline 3 & I have a sympathy with workers and I take in account of their concerns. & 22 & 73.30 & 08 & 36.0 & 00 & 00.0 \\
\hline 4 & $\begin{array}{l}\text { I have the capacity to innovate and to create new working and production } \\
\text { methods. }\end{array}$ & 19 & 63.30 & 08 & 26.7 & 03 & 10.0 \\
\hline 5 & Keep cool and avoid being angry & 16 & 53.30 & 11 & 36.7 & 03 & 10.0 \\
\hline 6 & Ease of decision-making & 14 & 46.70 & 08 & 26.7 & 08 & 26.7 \\
\hline 7 & Time control and management. & 13 & 43.30 & 15 & 50 & 02 & 06.7 \\
\hline 8 & Absence of anxiety while working & 11 & 36.70 & 11 & 36.7 & 08 & 26.7 \\
\hline
\end{tabular}

Table 6 shows that women entrepreneurs have the psychological characteristics necessary for their businesses. 


\subsection{Managerial Practices of Women Entrepreneurs}

Table 7. Managerial practices:

\begin{tabular}{|c|c|c|c|c|c|c|c|}
\hline \multicolumn{2}{|r|}{ Managerial practices of women entrepreneurs } & Yes & $\%$ & Some-times & $\%$ & No & $\%$ \\
\hline 1 & I follow up the works in person & 25 & 83.3 & 03 & 10.0 & 02 & 6.7 \\
\hline 2 & I prefer to execute the works on my way & 19 & 63.30 & 07 & 23.3 & 04 & 13.3 \\
\hline 3 & I consult my employees before making important decisions & 19 & 63.3 & 07 & 23.3 & 04 & 13.3 \\
\hline 4 & It is easy for me to communicate with women subordinates. & 19 & 63.3 & 07 & 23.3 & 04 & 13.3 \\
\hline 5 & I ask for advice from others in the management of my enterprise. & 18 & 60.0 & 08 & 26.7 & 04 & 13.3 \\
\hline 6 & It is easy for me to communicate with men subordinates. & 17 & 56.7 & 10 & 33.3 & 03 & 10.0 \\
\hline 7 & I Manage my enterprise by rigor to show my position of strength & 16 & 53.3 & 08 & 26.7 & 06 & 20.0 \\
\hline 8 & I have all instructions executed by subordinates. & 15 & 50.0 & 11 & 36.7 & 04 & 13.3 \\
\hline 9 & I delegate responsibilities to certain employees or collaborators & 15 & 50.0 & 11 & 36.7 & 04 & 13.3 \\
\hline 10 & My job is easily done without difficulties. & 10 & 33.3 & 08 & 26.7 & 12 & 40.0 \\
\hline 12 & I have no difficulties in communicating with my women subordinates. & 07 & 23.3 & 19 & 63.3 & 04 & 13.33 \\
\hline 8 & I have no difficulties in communicating with my subordinates. & 06 & 20.0 & 12 & 40.0 & 12 & 40.0 \\
\hline
\end{tabular}

The results in Table 7 show that women entrepreneurs involved in the investigation, master the basic skills needed to run their businesses.

\section{Discussions}

Results as exposed on tables (4 - 7) are discussed below in terms of socio-cultural environment of entrepreneurship, socio-cultural constraints of Women Entrepreneurs, psychological characteristics of women entrepreneurs and managerial competences of women entrepreneurs.

\subsection{Socio-cultural Environment of Entrepreneurship}

Management practices and human resource management methods are influenced by socio-cultural environment. Regarding the perception of women entrepreneurs by society, 19 women $(63.30 \%)$ stated that their status vis-à-vis the society has improved after the establishment of their businesses.

That is confirmed by the question whether there is a need for change in social attitudes to fit the socio-economic change. 16 women $(59.20 \%)$ consider that the success of women entrepreneurs requires a radical change in people's attitudes of Algerian society.

The entrepreneurial occupation of women is seen negatively by Algerian society, and only 11 responses $(36.70 \%)$ have recognized that society views positively their positions as woman entrepreneur.

Regarding cooperation between men and women entrepreneurs, 08 responses $(26.70 \%)$ found that the perception of male entrepreneurs to women entrepreneurs is significantly negative, and $(60.00 \%)$ found that they are not disturbed by men's harassment.

Women entrepreneurs are often harassed by men, mainly in administrations they have to work with. (23.30\%) of questioned women said they are harassed and (16.70) answered "some- times".

These findings confirm the results reached by Saskia, Kumar, Shastri \& Sinha $[6,3,7]$, stressing the impacts of socio-cultural environment on managerial performances of entrepreneurs in developing countries.

\subsection{Socio-cultural Constraints of Women Entrepreneurs}

Managers and employees are influenced by the culture of their environments. The Arab-Muslim culture and cultural traditions are nestled in Algeria as in all Maghreb countries. Among the cultural aspects found, women's work from their homes, the work of men under the supervision of managers or entrepreneurs women, male / female relationships at work, and formal / informal relations.

The majority of women entrepreneurs face environmental and socio-cultural constraints. The major problems of women entrepreneurs come from the attitudes of employees within the enterprise and the culture of the social environments. These cultural issues are related to many aspects of daily business management, as showed in Table 5.

The majority of women entrepreneurs (19), responded that employees are receptive to their directives $(63.13 \%)$. Regarding the fact of being managed by a woman, 15 responses $(50.00 \%)$, have shown that men employees accept to be supervised by women.

Among the cultural factors that influence the behavior of women entrepreneurs, we found competition, cooperation and jealousy. More than half of the women entrepreneurs $(60.00 \%)$ found that there is a competition between women entrepreneurs. In another question, $40 \%$ found that their competitors are jealous of them. 15 entrepreneurs (50.00) found that there is a jealousy between women entrepreneurs.

In response to the question concerning the cooperation 
between women entrepreneurs $(40.00 \%)$ responded that there is cooperation and (30.00) answered no to this question. And to a question if they prefer to deal with women entrepreneurs, 10 of them, that is $(30.30 \%)$ answered yes, and $(33.30 \%)$ prefer not to deal with women entrepreneurs.

To a question, whether their success is due to the fact they are women, only $(16.70 \%)$ of the sample responded that they do not think, that being women has an impact on their professional accomplishments; and $(30.00 \%)$ responded that the fact they are women does not cause them problems at work.

Women entrepreneurs in Algeria and in the Maghreb in general, are related to their culture, and cannot be dissociated from their Arab-Muslim identity. If the working conditions of Algerian women have changed dramatically, "the attitudes and perceptions of society are not sufficiently evolved" (Salman et al. [15] ).

Different responses show that women entrepreneurs face socio-cultural constraints due to the facts of attitudes, behaviors and practices of people in a male society.

\subsection{Psychological Characteristics of Women Entrepreneurs}

The results, as shown in Table 6, show that Algerian women entrepreneurs have strong personalities, marked by negotiating capacity $(86.70 \%)$, persuasions (80.00\%), sympathy with workers $(73.30 \%)$, capacity for innovation (63.30), ability to keep cool deal with difficult situations $(53.30 \%)$, and ease in decision making (46.70). These psychological attitudes demonstrate the abilities of women entrepreneurs, which facilitate the tasks of running their businesses. This proves also that women have personal and professional skills that allow them to overcome the toughest strains. They can even compete with men in fields used to be reserved exclusively for men.

In addition to these physical barriers that young entrepreneurs in general meet, there is the lack of human resource management experience. Women entrepreneurs are called to fight on several fronts, the family, the company (management, production, marketing, relations with the authorities - banks, taxes, suppliers and customers -).

Being a woman entrepreneur in the Arab-Muslim countries, requires psychological characteristics, such as intelligence, creativity, patience and the skills needed to manage their businesses. Human resource management methods must be adapted to the realities of the socio-cultural environment.

In addition to command and communication skills, the research results showed that mastering negotiation with partners, customers persuasive ability and contacts, sympathy with the workers and the inclusion of their concerns are needed for managerial success of women entrepreneurs.

The delegation of responsibilities to certain employees or collaborators remains moderate. The results of this study confirm that women, because of their psychological characteristics are more understanding to others, and more insistent and persistent on the success, even if their training is lacking.

\subsection{Managerial practices of Women Entrepreneurs}

Despite the limited number of women entrepreneurs in medium and large companies, there are several female executives and directors of public companies. That explains women's possession of managerial skills and success in accomplishing their tasks.

Based on the responses of the sample (Table 7), we find the following practices: monitoring the work in person $(83.3 \%)$, the execution of works according to their instructions $(63.30 \%)$, consultation with employees before making important decisions $(63.30 \%)$, asking for advice from others in the management of the enterprise $(60.00 \%)$, the management of company rigorously in order to show a position of strength $(53.30 \%)$ and the delegation of responsibilities to certain employees or collaborators $(50.00 \%)$.

Among the socio-cultural issues in the day to day management, we find communication between genders. The results showed that (17) answers mentioned, that they find no difficulty in communicating with their men subordinates $(56.70 \%)$, while $(63.30 \%)$ answered that they meet problem "from-time-to times" dealing with women subordinates.

Human resource management requires psychological and managerial skills and characters. Management methods must be adapted to the socio-cultural environment. This requires more practical research to better understand the HRM practices of female managers in Algeria and in developing countries in general.

These management practices demonstrate the capacity of women entrepreneurs to run their businesses, according to scientific standards. This confirms a study in Morocco on a sample of female heads of enterprises, that "women reported having various different strengths, which often explain their success. Strong personality, reliability, quality of listening and their perfection in the execution of work " (Salman et al, [15] ).

\section{Conclusions}

Results showed the impacts of socio-cultural environment on entrepreneurship in Algeria and on women entrepreneurs in particular. Algerian women entrepreneurs have the psychological characteristics as a result of their will to face the challenges of male society. Most of women entrepreneurs lack the appropriate training in $\mathrm{RH}$, they learnt from their experiences. The support staff, friends and family members helped to fill gaps encountered early in their careers as entrepreneurs.

They have proved themselves as business women, and the social and cultural attitudes of male society in Algeria are changing slowly but surely. 


\section{Appendix I}

\section{Indices of Socio-cultural Impacts on Managerial Performance (ISIMP) of women entrepreneurs}

In the context of a research on women entrepreneurs, we present you, madam, questions about the psychological characteristics and management practices related to women's entrepreneurship in Algerian society. Please answer the questions by putting an (x) in the appropriate boxes, according to your opinion and your management practices. There are no correct or incorrect answers; each entrepreneur has her own reality and her own experiences. Please, express your opinion honestly, since the results will be statistically analyzed and used for scientific purposes.

Thank you for your cooperation

1. Personal Information:

- Age: $20-30 \square$ 31-40 $\square$ 41-50 $\square 51$ and over $\square$

- Marital Status: single $\square$ married $\square$ divorced $\square$ widow $\square \square$

- Level of instruction: Elementary $\square$ Middle $\square$ Secondary $\square$ University $\square$

Field of study.

- Have you followed a training course? Yes

No

- If yes, which course?

- Is that the training has a relationship with your current activity? Yes $\square$ No

2. Information about the company:

- Sector of activity: Craft $\square$ Services $\square$ Industry $\square$ Civil service $\square$

- Nature of work:

\begin{tabular}{|c|c|c|c|c|}
\hline Nr. & Questions & yes & Some- times & No \\
\hline 1 & My status has improved vis-à-vis the society after creating my business. & & & \\
\hline 2 & The success female entrepreneurship requires a radical change of mentality. & & & \\
\hline 3 & Algerian society perceives positively the position of the woman entrepreneur. & & & \\
\hline 4 & The perception of men towards women entrepreneurs is significantly negative. & & & \\
\hline 5 & I am often harassed by men. & & & \\
\hline 6 & My employees are receptive to my instructions. & & & \\
\hline 7 & There is a competition between women entrepreneurs. & & & \\
\hline 8 & My subordinates accept to be headed by a woman & & & \\
\hline 9 & There a jealousy between women entrepreneurs. & & & \\
\hline 10 & There is a cooperation between women entrepreneurs. & & & \\
\hline 11 & My competitors are jealous of me. & & & \\
\hline 12 & I prefer to deal with women entrepreneurs. & & & \\
\hline 13 & The fact that I am a woman does not pose any problems for my business. & & & \\
\hline 14 & I master the negotiation with my interlocutors. & & & \\
\hline 15 & I have the ability to persuade my clients and my partners. & & & \\
\hline 16 & I have a sympathy with workers and I take in account of their concerns. & & & \\
\hline 17 & I have the capacity to innovate and to create new working and production methods. & & & \\
\hline 18 & Keep cool and avoid being angry & & & \\
\hline 19 & Ease of decision-making & & & \\
\hline 20 & Time control and management. & & & \\
\hline 21 & Absence of anxiety while working & & & \\
\hline 22 & I follow up the works in person & & & \\
\hline 23 & I prefer to execute the works on my way & & & \\
\hline 24 & I consult my employees before making important decisions & & & \\
\hline 25 & It is easy for me to communicate with women subordinates. & & & \\
\hline 26 & I ask for advice from others in the management of my enterprise. & & & \\
\hline 27 & It is easy for me to communicate with men subordinates. & & & \\
\hline 28 & I Manage my enterprise by rigor to show my position of strength & & & \\
\hline 29 & I have all instructions executed by subordinates. & & & \\
\hline 30 & I delegate responsibilities to certain employees or collaborators & & & \\
\hline 31 & My job is easily done without difficulties. & & & \\
\hline 32 & The confrontation of difficult situations does not bother me much. & & & \\
\hline 33 & I have no difficulties in communicating with my women subordinates. & & & \\
\hline 34 & I have no difficulties in communicating with my subordinates. & & & \\
\hline
\end{tabular}

-More comments on the psychological characteristics and socio-cultural challenges of women entrepreneurs: 


\section{REFERENCES}

[1] P. O. Adebayo, Impact of Socio-cultural Values and Individual Attributes on Women Entrepreneurship. International Journal of Management Sciences and Business Research, Dec. Vol, 4, Issue 12. 2015.

[2] F. Rachdi, L'entreprenariat féminin au Maroc: une étude exploratoire, $8^{\mathrm{e}}$ CIFEPME, 25 - 27 octobre, Haute Ecole de Gestion, Fribourg, Suisse. 2006.

[3] D. Kumar, Socio-Cultural Influence on Women Entrepreneurs: A Study of Uttarakhand State. International Journal of Trade and Commerce, 3(1) 337-351, 2014

[4] Z. Yakubu, Entrepreneurs at home: secluded Muslim women and hidden economic activities in Northern Nigeria. Nordic Journal of African Studies, 10 (1): 107-123. 2001.

[5] A. Bensedik, E. Ouchallal. La dimension psychologique dans la réussite entrepreneuriale. Les Cahiers du CREAD n ${ }^{\circ} 90$. pp. 131-156. 2009.

[6] V. Saskia. Women Entrepreneurship Promotion in Developing Countries: What explains the gender gap in entrepreneurship and how to close it? 1 March 2. Working Paper No. 2013/08. Maastricht School of Management, The Netherlands. 2013.

[7] R. K. Shastri, \& A. Sinha. The socio-cultural and economic effect on the development of women entrepreneurs. Asian Journal of Business Management2 (2), 30-34. 2010.

[8] A.Dif, G. Benyahia-Taibi, L'entrepreneuriat féminin : Etudes de cas des entrepreneures de la wilaya d'Oran. Journées Scientifiques Internationale sue l'Entrepreneuriat : Formation et opportunités d'affaires. Biscra, 6-8 Avril, 2010.

[9] A. Cornet, C. Constantinidis, Entreprendre au féminin : une réalité multiple et des attentes différenciées, Revue française de gestion 4/ ( $\left.n^{\circ} 151\right)$, p. 191-204, 2004.

[10] Y. Gasse, Functional Diversity in University Entrepreneurship Development : The Laval University Model", in Teresa V. Menzies ed.-, Entrepreneurship and the Canadian Universities, St. Catharines, Ont., Brock University, chapter 11, p. 71- 76, 2002.

[11] S. ZIANE S, Les jeunes entrepreneurs en Algérie: Profil psychosociologique et contraintes environnementales. Revue Science Humaines (Université Mentouri, Constantine, Algérie). n³3, juin, pp.67-81, 2010.

[12] C. Léger-Jarniou, Developing entrepreneurial culture among young people, French Review of Management 5 (No. 185), 161-174, 2008 .

[13] A. Tounés, L'ENTREPRENEUR : l'odyssée d'un concept. Cahier de recherche $\mathrm{N}^{\circ}$ 03-73 du réseau de chercheurs «entrepreneuriat», 2003.

[14] B. Ghiat, Culture et innovation managériale des femmesentrepreneurs en Algérie. Colloque international Innovation entrepreneuriale \& développement durable. Institut Euro-Africain de Management (INSEAM). Strate Collège - Paris. 20-21 Février, 2014.

[15] N.Salman, M. Al-Abboudi, et S. Henda, Les femmes chefs d'entreprises au Maroc, $11^{\mathrm{e}}$ CIFEPME, Brest, 24-26 octobre, 2012. 